\title{
Faktor-Faktor Kritis Kesuksesan Proyek Terhadap Kinerja Proyek di PT Wijaya Karya (Persero) Tbk
}

\author{
Sutikno ${ }^{1^{*}}$ \\ ${ }^{1}$ PT Wijaya Karya (Persero) Tbk, Jakarta, Indonesia
}

\section{Article Info}

Article history:

Received: 18 August 2017;

Accepted: 18 October 2017;

Published: 31 October 2017.

Keywords:

Project management office; Project management system; Site condition; Owner involvment; Project management team capacity and project performance.

\begin{abstract}
This article aims to determine the effect of the project office management variable, project management system, site conditions, owner involvement, and the capacity of the project management team. The research method used survey. Respondents numbered 250 people. Data analysis using Structural Equation Modeling (SEM). The results show that the variables of the project management office, project management system, site conditions, owner involvement, and project management team capacity have a positive effect on project performance at PT. Wijaya Karya (Persero) Tbk.
\end{abstract}

How to Cite:

Sutikno, S. (2017, October 31). Faktor-faktor Kritis Kesuksesan Proyek Terhadap Kinerja Proyek di PT Wijaya Karya (Persero) TBK. Jurnal Pendidikan Ekonomi \& Bisnis, 5(2), 206-214. https://doi.org/https://doi.org/10.21009/JPEB.005.2.7

* Corresponding Author. 


\section{PENDAHULUAN}

Sektor jasa konstruksi merupakan salah satu kegiatan yang memberikan kontribusi yang sangat penting dalam perkembangan perekonomian dan pertumbuhan suatu bangsa, termasuk Indonesia. Menurut perkiraan Gapensi (Gabungan Pelaksana Konstruksi), bahwa kontribusi sektor konstruksi bisa mencapai sekitar $16 \%$ terhadap Produk Domestik Bruto (PDB), (Harian Jurnal Asia (http://www.jurnalasia.id, 2015).

Kegiatan sektor ini memberikan efek berantai pada sektor lain seperti sektor keuangan, bahan baku, industri, peralatan, ketenagakerjaan, transportasi, sistem manajemen, dan lain-lain. Aktivitas ini juga memberikan gambaran seberapa besar tingkat pertumbuhan dan pembangunan bangsa ini, semakin besar pasar konstruksi menggambarkan bahwa pembangunan bangsa sedang berlangsung secara besar pula, demikian pula sebaliknya.

Kinerja suatu proyek dipengaruhi oleh beberapa hal utama dan beberapa hal pendukung lainnya. Performance atau kinerja adalah merupakan hasil atau keluaran dari suatu proses (Nurlaila, 2010). Dilihat dari pendekatan perilaku dalam manajemen, kinerja adalah kuantitas atau kualitas sesuatu yang dihasilkan atau jasa yang diberikan oleh seseorang yang melakukan pekerjaan (Luthans, 2005).

Kinerja adalah tingkat keberhasilan kerja, yaitu perbandingan antara hasil kerja dengan standar yang ditetapkan (Dessler, 2000). Kinerja adalah hasil kerja baik secara kualitas maupun kuantitas yang dicapai oleh seseorang atau tim dalam melaksanakan tugas sesuai tanggung jawab yang diberikan (Mangkunegara, 2002).

Kinerja adalah hasil atau tingkat keberhasilan seseorang secara keseluruhan selama periode tertentu dalam melaksanakan tugas dibanding-kan dengan berbagai kemungkinan, seperti standar hasil kerja, target atau sasaran atau kriteria yang telah ditentukan terlebih dahulu telah disepakati bersama (Rivai, 2005). Kinerja Proyek merupakan hasil kerja dari tim proyek tersebut dalam melaksanakan kontrak kerja yang disepakati oleh pihak pemilik proyek dan kontraktor pelaksana.

Berdasarkan definisi-definisi di atas, dapat dipahami bahwa kinerja dapat diartikan sebagai hasil akhir dari keseluruhan proses yang dilakukan oleh proyek dengan kriteria-kriteria yang telah ditetapkan. Kinerja juga menggambarkan prestasi yang dicapai oleh suatu organisasi dan individuindividu yang ada di dalamnya. Selanjutnya, berdasarkan penelitian-penelitian ter-dahulu ditemukan bahwa Critical Success Factor (CSF) dapat diambil kesamaan dari sejumlah peneliti dan penulis.

Manajemen kantor pusat merupakan organisasi yang ada di kantor pusat yang membawahi proyek yang terkait, dengan berbagai macam tugas dan tanggung jawab di antaranya adalah koordinasi dengan manajemen proyek serta berperan sebagai fungsi pendukung. Manajemen kantor pusat dibentuk dengan beberapa alasan: (1) untuk mengurangi risiko proyek dalam hal kegagalan memenuhi target waktu, biaya dan spesifikasi; (2) meningkatkan kesuksesan proyek dan program penyampaian nilai-nilai perusahaan yang diharapkan; (3) membuat penggunaan sumber daya yang lebih efisien dan, (4) membuat lebih efektif dalam penggunaan keahlian dan sumber daya untuk lintas proyek dan program

Menurut Crawford (2011), dalam penelitiannya menyim-pulkan bahwa manajemen proyek yang terkait dengan manajemen kantor pusat dalam mengelola proyek yaitu perlu fokus pada pengukuran kinerja, strategi penyelarasan, manajemen laporan dan pengelolaan permintaan sumber daya proyek.

Menurut Izadpanah (2012), manajemen kantor pusat adalah konsep baru. Perubahan dari pengelolaan proyek secara tradisional menjadi pengelolaan dengan strategi dapat menciptakan banyak faktor kesuksesan proyek. Monitoring kinerja proyek, didukung oleh software manajemen proyek dan persiapan metodologi manajemen proyek adalah fungsi-fungsi yang penting. Organisasi menggunakan manajemen kantor pusat untuk mencapai tujuan 
utama proyek yaitu mutu, waktu dan biaya. Penelitian menemukan bahwa banyak tantangan yang sangat signifikan dalam penerapan manajemen kantor pusat adalah risiko perubahan budaya organisasi dan kurangnya staf professional.

Untuk dapat melaksanakan proyek dengan baik dibutuhkan sistem manajemen proyek yang baik dimana dengan sistem tersebut pelaksanaan proyek akan lebih terarah, terkontrol dan terprediksi hasil akhirnya. Menurut Cooke \& Davies (2009), Zulu (2007), yang melakukan penelitian di United Kingdom menyimpulkan bahwa penerapan sistem manajemen yang baik akan memberikan dampak yang signifikan. Menurut Carcano (2015), bahwa dengan time management yang merupakan bagaian dari sistem manajemen proyek, maka realisasi penyelesaian pekerjaan akan secara signifikan lebih cepat. Sementara Khatab (2016), berkesimpulan bahwa sistem manajemen pelaksanaan proyek berdampak yang sangat positif terhadap kinerja proyek.

Lokasi proyek konstruksi tersebar di seluruh kondisi wilayah seperti wilayah perkotaan, perumahan, perkebunan, hutan, pelabuhan, pulau terpencil, ada jalur transport regular dan lain-lain. Juga tipikal masyarakat sekitarnya bervariasi, ada masyarakat perkotaan, masyarakat pekerja, masyarakat terbelakang atau majemuk. Pemahaman kondisi lapangan dan masyarakat setempat secara baik dapat menjadi data yang akurat yang akan dipakai dalam perencanaan, pengendalian dan proyeksi penyelesaian proyek, sehingga secara umum proyek bisa dilaksanakan dengan terkendali.

Menurut Akanni (2015), yang melakukan penelitian di Nigeria menyimpulkan bahwa waktu dan biaya adalah sangat terkait erat dengan situasi ekonomi dan politik, sementara faktor sosial dan kultur terkait secara signifikan. Peneliti merekomendasikan kepada stakeholder untuk mengambil langkah-langkah yang memadai untuk mengatasi faktor-faktor ini dan menyiapkan budget yang mencukupi. Menurut Sudawi (2012), proyek yang terpencil mempunyai maslah yang unik sehingga dibutuhkan pengelolaan yang sistematik untuk mendapatkan kinerja yang memuaskan.

Pemilik proyek atau pemberi kerja adalah pihak yang memiliki proyek atau pekerjaan dan memberikanya kepada kontraktor yang ditunjuknya yang dinilai mampu dengan harga yang masuk akal. Pemilik proyek bertanggung jawab memastikan bahwa proyek yang dilaksanakan adalah sesuai dengan keinginannya yang tertuang dalam dokumen tender dan pasal-pasal kontrak yang sudah disepakai bersama.

Menurut Shaokai (Hao, 2012), yang melakukan penelitain pada kontraktor di China menyimpulkan bahwa pemilik proyek dapat mempengaruhi kontraktor berdasarkan kepercayaan tanpa pemaksaan. Bagaimanapun pemaksaan yang moderat adalah diperlukan dalam hubungan antara kekuasaan dan perintah atas dasar kepercayaan. Dalam hubungan itu akan semakin positif apabila level power lebih rendah. Lebih dari itu kepercayaan mempengaruhi secara lebih positif dalam peningkatan kinerja.

Menurut Trigunarsyah dan AlSolaiman (2015), dalam penelitannya di Arab Saudi menemukan bahwa dari analisa faktor diperoleh bahwa faktor individu dari pemilik proyek dapat mempengaruhi kinerja proyek yaitu keterlibatan pemilik proyek, pengetahuan dan pengalaman dalam memberikan keputusan, kemampuan komunikasi, kepuasan kerja, kemampuan personal, keahlian dalam disain dan konstruksi.

Manajemen proyek adalah organisasi dengan tugas utama merencanakan, mengorganisasi, memimpin dan mengendalikan sumber daya proyek yang berupa material, peralatan dan tenaga kerja serta mempunyai sasaran yang telah digariskan secara spesifik seperti waktu, biaya dan spesifikasi teknis lainnya.

Menurut Stare (2011), yang melakukan penelitian di Slovenia menyimpulkan bahwa budaya organisasi mempunyai dampak yang tinggi dalam kinerja proyek. Peningkatan wewenang manajer proyek dalam tipe organisasi tertentu berdampak positif terhadap kinerja proyek. Cara penanganan 
dari tim adalah sangat penting dalam menentukan keberhasilan proyek

Menurut Isabel (2014), tujuan utama pada proses pekerjaan adalah memproleh tim dan pimpinan yang paling sesuai dengan karakteristik proyek agar terbentuk tim yang tangguh. Sementara menurut Anantatmula (2010), dari Carolina University menyimpulkan bahwa pendefinisian kriteria proyek sukses adalah tahapan yang sangat penting untuk membuat proyek akan sukses. Hal ini akan menjadi landasan dalam membuat sesuatu yang jelas, komunikasi yang diharapkan, proses konsistensi karyawan. Tujuan utama manajer proyek adalah membuat kepercayaan dan kepemimpinan

Menurut Takim dan Akintoye (Takim, 2002), indikator kinerja utama memiliki tujuh parameter yaitu: biaya konstruksi, waktu pelaksanaan dan prediksi biaya, prediksi waktu, kerusakan dan kepuasan pelanggan terhadap produk serta pelayanan.

Menurut Izadpanah (2012), Crawford (2011) dan Magnusdottir (2012), manajemen kantor pusat yang modern yang dibuat khusus bisa memberikan dampak yang positif pada kinerja proyek. Kemudian menurut Alias (2013), Chan (2004) dan Walker (1997), bahwa pengelolaan project procedure dan project management system yang baik dapat memberikan dampak yang positif pada kinerja proyek.

Selanjutnya Akanni (2015), Sidawi (2012) dan Sweis (2014), sampai pada kesimpulan bahwa kondisi lapangan berpengaruh signifikan terhadap kinerja proyek. Dan menurut Trigunarsyah (2015), Shaokai Lu (Hao, 2012) dan Alsolaiman (2014), mereka berkesimpulan bahwa kontribusi pemilik proyek berpengaruh terhadap kinerja proyek.

Sementara menurut Nyandika \& Ngugi (Nyandika, 2014), ada hubungan yang positif signifikan antara sumber daya stakeholder dan kinerja proyek jalan di Kenya. Menurut Anantatmula (Anantatmula, 2010), Isabel (Isabel C., 2014) dan Stare (2011), menyimpulkan yang senada yaitu bahwa manajemen proyek sangat berkontribusi dalam hasil kinerja proyek. Sementara menurut Babu \& Sudhakar (2015), banyak faktor kesuksesan proyek yang penting seperti faktor yang terkait dengan kapasitas manajer proyek, organisasi dan lingkungan luar.

Sedangkan menurut Saqib, Faroukoi dan Lodi (Saqib, 2008), lima besar faktor penting untuk kesuksesan proyek adalah: faktor kontraktor, faktor manajer proyek, faktor pengadaan, faktor desain dan faktor manajemen proyek.

Mencermati data obyek yang akan menjadi obyek penelitian yaitu data kinerja proyek-proyek di PT. Wijaya Karya (Persero) Tbk, dapat diketahui bahwa tidak ada pergerakan yang membentuk irama tertentu mengenai kinerja proyek-proyek. Dari data yang ada juga nampak bahwa kondisi sistem manajemen proyek yang baik tidak serta merta menunjukkan kinerja yang baik. Demikian juga kondisi lapangan yang berat tidak mesti berakhir dengan kinerja yang buruk pula.

Dengan penjelasan dan data-data yang ada terlihat bahwa betapa sangat pentingnya kinerja proyek yang baik, yang mana hal ini akan mengantarkan kinerja perusahaan yang baik pula dan pada akhirnya akan mendukung pertumbuhan perusahaan untuk memenangkan persaingan serta tumbuh menjadi perusahaan yang makin besar.

\section{METODE}

Penelitian ini menggunakan metode penelitian deskriptif dan kausal. Menurut Malhotra (2005), penelitian deskriptif dan kausal sering kali disebut penelitian konklusif (conclusive), sebab keduanya berusaha memberikan kesimpulan akhir (conclusion). Penelitian deskriptif adalah jenis riset konklusif dengan tujuan utama menguraikan sesuatu. Pendekatan yang dipakai itu dipakai sebagai alat melihat dan menggali yang dapat dilakukan sepanjang melakukan penelitian. Dalam penelitian ini akan mendeskripsikan bahwa manajemen kantor pusat, kondisi kontraktual, kondisi lapangan, keterlibatan pemilik proyek, kualitas manajemen proyek berpengaruh seberapa besar terhadap 
kinerja perusahaan.

Populasi dalam penelitian ini adalah Pegawai dengan level manajerial kantor dan proyek di lingkungan PT. Wijaya Karya (Persero), Tbk. sebanyak 500 orang diantara jumlah pegawai tetap sebanyak 2.089 orang dan pegawai tidak tetap sekitar 1.200 orang.

Metode pengambilan sampel dalam penelitian ini adalah purporsive sampling adalah cara pengambilan sampel dari populasi dengan kriteria tertentu sesuai dengan tujuan, kemudian dilanjutkan dengan sistem random sederhana yaitu dengan cara mengambil secara langsung secara acak dari populasinya yang sudah dipilih. Teknik pengambilan sampel yang digunakan adalah dengan kuesioner.

\section{HASIL DAN PEMBAHASAN}

Pada penelitian ini, subyek yang diteliti adalah Pegawai dengan level manajerial kantor dan proyek di lingkungan PT. Wijaya Karya (Persero), Tbk. Dari keseluruhan kuesioner yang telah disebarkan secara online peneliti mendapatkan 250 responden. Jumlah tersebut tentu saja telah melebihi jumlah minimal yang ditetapkan oleh peneliti sebelumnya yaitu sebanyak 245 responden. Selanjutnya, responden diidentifikasikan berdasarkan jenis kelamin, masa kerja, pendidikan, jabatan. Identifikasi ini perlu dilakukan untuk mengetahui karateristik umum pada setiap responden penelitian. Data deskriptif tentang karateristik umum responden dapat dilihat pada tabel 1 .
Berdasarkan dari hasil profil responden yang didapatkan, terlihat bahwa mayoritas responden memiliki jenis kelamin lakilaki yaitu sebanyak 231 orang (92,4\%), sedangkan responden dengan jenis kelamin perempuan sebanyak 19 orang $(7,6 \%)$.

Pada karakteristik responden selanjutnya mayoritas responden memiliki masa kerja $>10$ tahun yaitu sebanyak 123 orang (49,2\%), diikuti oleh responden dengan masa kerja 5 - 10 tahun sebanyak 97 orang $(38,8 \%)$, dan responden dengan masa kerja $<5$ tahun sebanyak 30 orang (12\%).

Untuk karakteristik pendidikan, mayoritas responden memiliki pendidikan Sarjana (S1/S2/S3) yaitu sebanyak 219 orang $(87,6 \%)$, diikuti oleh responden yang memiliki pendidikan diploma sebanyak 16 orang $(6,4 \%)$ dan responden yang memiliki pendidikan SLTA sebanyak 15 orang $(6,0 \%)$. Selain itu mayoritas responden memiliki jabatan manajemen proyek sebanyak 150 orang $(60,0 \%)$, diikuti oleh responden yang memiliki jabatan manajemen kantor pusat yaitu sebanyak 62 orang $(24,8 \%)$, dan responden yang memiliki jabatan pimpinan proyek sebanyak 38 orang $(15,2 \%)$.

Studi aktual dilakukan dengan tujuan untuk menguji hipotesis yang akan digunakan untuk menjawab setiap tujuan dari penelitian ini. Penelitian ini menggunakan metode Structural Equation Modelling (SEM) dan multiple regression. Setelah pengolahan confirmatory analysis dan goodness of fit selanjutnya adalah pengolahan struc-

Tabel 1. Profil Responden

\begin{tabular}{cccc}
\hline Kategori & Karakteristik & Jumlah & $\begin{array}{c}\text { Persentase } \\
\text { (\%) }\end{array}$ \\
\hline \multirow{2}{*}{ Jenis Kelamin } & Laki-laki & 231 & 92,4 \\
& Perempuan & 19 & 7,6 \\
Masa Kerja & -5 tahun & 30 & 12,0 \\
& - 10 tahun & 97 & 38,8 \\
Pendidikan & 10 tahun & 123 & 49,2 \\
Terakhir & SLTA & 15 & 6,0 \\
& Diploma & 16 & 6,4 \\
Jabatan & Sarjana (S1/S2/S3) & 219 & 87,6 \\
Responden & Pimpinan Proyek & 38 & 15,2 \\
& Manajemen Proyek & 150 & 60,0 \\
& Manajemen Kantor & 62 & 24,8 \\
\hline
\end{tabular}


tural model untuk melihat hubunganhubungan antar variabel. Pengujian untuk melihat hubungan antar variabel dependen dan variabel indenden yang dapat dilihat dari $t$-value dan $p$-value daripada hubungan antar variabel dari penelitian ini. Hasil dari pengolahan structural model dapat dilihat pada tabel 2 .

Dari tabel 2 dapat dilihat bahwa nilai $t$-value untuk hubungan antar variabel yang didukung berada diatas nilai $t$ hitung yaitu 1,96 dan $p$-value juga berada dibawah signifikansi 0,05 yang berarti bahwa pengaruh daripada tiap-tiap hubungan tersebut didukung pula. Berdasarkan hasil tersebut, dapat diambil kesimpulan bahwa seluruh hipotesis hubungan langsung diterima karena memiliki nilai $t$-value diatas 1,96 dan nilai $\mathrm{p}$ di bawah 0,05. Seluruh hubungan yang terjadi memiliki koefisien yang positif sehingga pengaruh yang terjadi merupakan hubungan yang searah. Hasilnya perhitungan Sobel test untuk melihat besaran pengaruh tidak langsung dapat dilihat pada Tabel 3.

Berdasarkan pada Tabel 3, dapat dilihat pernyataan pada Hipotesis 10 (H10) yang menyatakan bahwa terdapat pengaruh tidak langsung antara manajemen kantor pusat terhadap kinerja proyek melalui kualitas tim manajemen proyek diterima. Hal ini disebabkan oleh nilai Sobel test sebesar 3,322 yang bernilai $\geq 1,96$. Demikian juga H11, H12 dan H13.

\section{KESIMPULAN DAN SARAN}

Berdasarkan hasil analisis diketahui bahwa manajemen kantor pusat, sistem manajemen proyek, kondisi lapangan dan keterlibatan pemilik proyek berpengaruh terhadap kualitas tim manajemen proyek

Tabel 2. Hasil Pengujian Hipotesis (H) Pengaruh Langsung

\begin{tabular}{|c|c|c|c|c|c|c|}
\hline $\mathbf{H}$ & Path & Estimate & S.E. & C.R. & $\mathbf{P}$ & Keterangan \\
\hline H1 & $\begin{array}{l}\text { Manajemen kantor } \\
\text { pusat } \rightarrow \text { Kualitas tim } \\
\text { manajemen proyek }\end{array}$ & 0,193 & 0,049 & 3,893 & 0,000 & Berpengaruh \\
\hline $\mathrm{H} 2$ & $\begin{array}{l}\text { Sistem manajemen } \\
\text { proyek } \rightarrow \text { Kualitas tim } \\
\text { manajemen proyek }\end{array}$ & 0,225 & 0,057 & 3,967 & 0,000 & Berpengaruh \\
\hline H3 & $\begin{array}{l}\text { Kondisi lapangan } \rightarrow \\
\text { Kualitas tim } \\
\text { manajemen proyek }\end{array}$ & 0,226 & 0,059 & 3,847 & 0,000 & Berpengaruh \\
\hline $\mathrm{H} 4$ & $\begin{array}{l}\text { Keterlibatan pemilik } \\
\text { proyek } \rightarrow \text { Kualitas tim } \\
\text { manajemen proyek }\end{array}$ & 0,159 & 0,052 & 3,088 & 0,002 & Berpengaruh \\
\hline H5 & $\begin{array}{l}\text { Kualitas tim } \\
\text { manajemen proyek } \rightarrow \\
\text { Kinerja proyek }\end{array}$ & 0,753 & 0,118 & 6,365 & 0,000 & Berpengaruh \\
\hline H6 & $\begin{array}{l}\text { Manajemen kantor } \\
\text { pusat } \rightarrow \text { Kinerja } \\
\text { proyek }\end{array}$ & 0,112 & 0,037 & 3,010 & 0,003 & Berpengaruh \\
\hline H7 & $\begin{array}{l}\text { Sistem manajemen } \\
\text { proyek } \rightarrow \text { Kinerja } \\
\text { proyek }\end{array}$ & 0,204 & 0,045 & 4,540 & 0,000 & Berpengaruh \\
\hline H8 & $\begin{array}{l}\text { Kondisi lapangan } \rightarrow \\
\text { Kinerja proyek }\end{array}$ & 0,212 & 0,047 & 4,516 & 0,000 & Berpengaruh \\
\hline H9 & $\begin{array}{l}\text { Keterlibatan pemilik } \\
\text { proyek } \rightarrow \text { Kinerja } \\
\text { proyek }\end{array}$ & 0,077 & 0,038 & 2,020 & 0,043 & Berpengaruh \\
\hline
\end{tabular}


dan kinerja proyek.

Hipotesis pertama (H1) yang menyatakan bahwa manajemen kantor pusat berpengaruh terhadap kualitas tim manajemen proyek adalah diterima. Hal ini dapat dilihat dari nilai CR $(3,893)$ yang lebih besar dari $\pm 1,98$ dengan probabilitas sebesar 0,000 di bawah nilai 0,05 (taraf nyata $\alpha=5 \%$ ).

Hipotesis kedua (H2) sistem manajemen proyek berpengaruh terhadap kualitas tim manajemen proyek adalah diterima. Hal ini dapat dilihat dari nilai CR $(3,967)$ yang lebih besar dari $\pm 1,98$ dengan probabilitas sebesar $0,000 \mathrm{di}$ bawah nilai 0,05 (taraf nyata $\alpha=5 \%$ ).

Hipotesis ketiga (H3) yang menyatakan bahwa kondisi lapangan berpengaruh terhadap kualitas tim manajemen proyek adalah diterima. Hal ini dapat dilihat nilai CR $(3,847)$ yang lebih besar dari $\pm 1,98$ dengan probabilitas sebesar 0,000 yang lebih kecil dari 0,05 (taraf nyata $\alpha=5 \%)$.

Hipotesis ke empat (H4) yang menyatakan bahwa keterlibatan pemilik proyek berpengaruh terhadap kualitas tim manajemen proyek adalah diterima. Hal ini dapat dilihat nilai CR $(3,088)$ yang lebih besar dari \pm 1.98 dengan probabilitas sebesar 0,002 yang berada di bawah nilai 0,05 (taraf nyata $a=5 \%$ ).

Hipotesis kelima (H5) yang menyatakan bahwa kualitas tim manajemen proyek berpengaruh terhadap kinerja proyek adalah diterima. Hal ini dapat dilihat dari nilai CR $(6,365)$ yang lebih besar dari $\pm 1,98$ dengan probabilitas sebesar 0,000 yang berada di bawah nilai 0,05 (taraf nyata $\alpha=5 \%)$.

Hipotesis keenam (H6) yang menyatakan bahwa manajemen kantor pusat berpengaruh terhadap kinerja proyek adalah diterima. Hal ini dapat dilihat dari nilai CR $(3,010)$ yang lebih besar dari $\pm 1,98$ dengan probabilitas sebesar 0,003 yang berada di bawah nilai 0,05 (taraf nyata $\alpha=5 \%$ ).

Hipotesis ketujuh (H7) sistem manajemen proyek berpengaruh terhadap kinerja proyek adalah diterima. Hal ini dapat dilihat dari nilai CR $(4,540)$ yang lebih besar dari $\pm 1,98$ dengan probabilitas sebesar 0,000 yang berada di bawah nilai 0,05 (taraf nyata $\alpha=5 \%$ ).

Hipotesis kedelapan (H8) yang menyatakan bahwa kondisi lapangan berpengaruh terhadap kinerja proyek adalah diterima. Hal ini dapat dilihat nilai CR

Tabel 3. Hasil Pengujian Hipotesis Pengaruh Tidak Langsung

\begin{tabular}{clcc}
\hline H & \multicolumn{1}{c}{ Path } & Sobel Test & Kesimpulan \\
\hline H10 & $\begin{array}{l}\text { Manajemen kantor pusat } \rightarrow \text { Kualitas } \\
\text { tim manajemen proyek } \rightarrow \text { Kinerja } \\
\text { proyek }\end{array}$ & 3,322 & Berpengaruh \\
& $\begin{array}{l}\text { Sistem manajemen proyek } \rightarrow \text { Kualitas } \\
\text { H11 }\end{array}$ & & \\
& $\begin{array}{l}\text { tim manajemen proyek } \rightarrow \text { Kinerja } \\
\text { proyek }\end{array}$ & 3,328 & Berpengaruh \\
H12 & $\begin{array}{l}\text { Kondisi lapangan } \rightarrow \text { Kualitas tim } \\
\text { manajemen proyek } \rightarrow \text { Kinerja proyek }\end{array}$ & 3,255 & Berpengaruh \\
& $\begin{array}{l}\text { Keterlibatan pemilik proyek } \rightarrow \\
\text { H13 }\end{array}$ & $\begin{array}{l}\text { Kualitas tim manajemen proyek } \rightarrow \\
\text { Kinerja proyek }\end{array}$ & 2,730 \\
\hline
\end{tabular}


$(4,516)$ yang lebih besar dari $+1,98$ dengan probabilitas sebesar 0,000 yang lebih kecil dari 0,05 (taraf nyata $\alpha=5 \%$ ).

Hipotesis kesembilan (H9) yang menyatakan bahwa keterlibatan pemilik proyek berpengaruh terhadap kinerja proyek adalah diterima. Hal ini dapat dilihat nilai CR $(2,020)$ yang lebih besar dari \pm 1.98 dengan probabilitas sebesar 0,043 yang berada di bawah nilai 0,05 (taraf nyata $\alpha=5 \%)$.

Hipotesis kesepuluh (H10) yang menyatakan bahwa manajemen kantor pusat berpengaruh terhadap kinerja proyek secara tidak langsung melalui kualitas tim manajemen adalah diterima. Hal ini dapat dilihat dari nilai Sobel test $(3,322)$ yang lebih besar dari $\pm 1,98$.

Hipotesis kesebelas (H11) sistem manajemen proyek berpengaruh terhadap kinerja proyek secara tidak langsung melalui kualitas tim manajemen adalah diterima. Hal ini dapat dilihat dari nilai Sobel test $(3,328)$ yang lebih besar dari $\pm 1,98$.

Hipotesis kedua belas (H12) yang menyatakan bahwa kondisi lapangan berpengaruh terhadap kinerja proyek secara tidak langsung melalui kualitas tim manajemen adalah diterima. Hal ini dapat dilihat nilai Sobel test $(3,255)$ yang lebih besar dari $\pm 1,98$.

Hipotesis ketiga belas (H13) yang menyatakan bahwa keterlibatan pemilik proyek berpengaruh terhadap kinerja proyek secara tidak langsung melalui kualitas tim manajemen adalah diterima. Hal ini dapat dilihat nilai Sobel test $(2,730)$ yang lebih besar dari \pm 1.98 .

Di antara lima variabel yang berpengaruh terhadap kinerja proyek, yang paling signifikan pengaruhnya secara langsung adalah kualitas tim manajemen proyek. Berdasarkan uraian-uraian di atas, maka penelitian mendatang hendaknya melakukan replikasi penelitian untuk daerah penelitian yang lebih luas. Replikasi penelitian juga dapat dilakukan tidak terbatas pada satu perusahaan saja, tetapi dapat diperluas ke perusahaan-perusahaan yang lain, dengan harapan akan membantu mendapatkan sampel yang lebih baik sehingga diharapkan mendapatkan hasil yang lebih akurat. Penelitian mendatang hendaknya juga dengan menguji dan menambah variabel-variabel baru seperti jenis proyek, motivasi tim proyek dan lain-lain.

\section{DAFTAR PUSTAKA}

Anantatmula, S. (2010). Project Manager Leadership Role in Improving Project Performance. Engineering Management Journal, Vol. 22 (1).

Babu, S. \&. (2015). Critical Success Factors Influencing Performance of Construction Projects. International Journal of Innovative Research in Science, Engineering and Technology, Vol. 4 (5).

Carcaño R.G.S, S. G. (2015). The Use of Project Time Management Processes and the Schedule Performance of Construction Projects in Mexico. Journal of Construction Engineering .

Crawford, K. (2011). Lessons From the Best: Practices of the World's Top PMOs. PMI Global Congress Proceedings. Dallas, TX.

Fokus Kembangkan Sektor Konstruksi Gairahkan Perekonomian. (2015). Harian Jurnal Asia .

Hao, S. L. (2012). The influence of owner power in fostering contractor cooperation. International Journal of Project Managemen, JPMA-01460, 10.

Isabel C., M. C. (2014). What team members perceive as important to achieve high performance.

Izadpanah, H. A. (2012). The Reality of Project Management Office for Construction Organization in the Oil, Gas and Petrochemical Industry of Iran. Research Journal of Applied Sciences, Engineering and Technology, Vol. 4 (15), 2515-2522.

Luthans, F. (2005). Organizational Behavior. New York: McGraw-hill.

Magnusdottir, B. (2012). Project Management Office in International Organizations. Chalmers University of Technology SE-412 96, CHALMERS Civil and En- 
vironmental Engineering, Master's Thesis, Gothenburg Sweden,.

Mangkunegara, A. P. (2002). Manajemen Sumber Daya Manusia. Bandung: Remaja Rosdakarya.

Nurlaila. (2010). Manajemen Sumber Daya Manusia (I ed.). LepKhair.

Nyandika, O. \&. (2014). Influence os Stakeholder's participation on performance of Road Project at Kenya National Highways Authority. European Journal of Business Management, Vol. 1 (11).

Rivai, V. \&. (2005). Peformance Appraisal: Sistem yang tepat untuk Menilai Kinerja Karyawan dan Meningkatkan Daya Saing Perusahan. Jakarta: PT. RajaGrafindo Persada.

Saqib, M. F. (2008). Assessment of Critical Success Factors for Construction Projects in Pakistan. First International Conference on Construction In Developing Countries (ICCIDC-I) "Advancing and Integrating Construction Education, Research \& Practice”. Karachi, Pakistan.

Takim, R. a. (2002). Performance Indicators for Successful Construction Project Performance. 18th Annual ARCOM Conference, Vol. 2, hal. 545-555. University of Northumbria, Greenwood, D (Ed.). 